DOI 10.22460/jpmi.v1i3.281-288

\title{
KEMAMPUAN BERPIKIR KRITIS MATEMATIS DAN SELF CONFIDENCE SISWA SMP MELALUI PENDEKATAN REALISTIC MATHEMATIC EDUCATION
}

\author{
Delina $^{1}$, M. Afrilianto ${ }^{2}$, Euis Eti Rohaeti ${ }^{3}$ \\ 1,2,3 IKIP Siliwangi, Jl. Terusan Jenderal Sudirman, Cimahi, Jawa Barat, Indonesia \\ 12delina2607@yahoo.com, ${ }^{2}$ muhammadafrilianto@ikipsiliwangi.ac.id, ${ }^{3}$ e2rht@ikipsiliwangi.ac.id
}

Diterima: 23 Februari 2018; Disetujui: 28 Mei 2018

\begin{abstract}
This research aims to examine of mathematical critical thinking ability of mathematic and self confidence of students who get Realistic Mathematic Education approach compared to those who get ordinary learning. The method used in this research is the experimental method. The population in this study were junior high school students in Purwakarta, while the sample was SMP Negeri 1 Plered and selected two classes randomly from all of the existing VII class. Then from the two classes are assigned randomly into the experimental class and control class. The experimental class received learning with Realistic Mathematic Education approach and control class gained regular learning. The instrument used is the test of critical thinking ability mathematically and scale self confidence. From the calculation and hypothesis test concluded that the improvement of critical thinking ability of mathematic and self confidence of students who get Realistic Mathematic Education approach is better than those who get regular learning.
\end{abstract}

Keywords: Critical Thinking, Self Confidence, Realistic Mathematic Education

\begin{abstract}
Abstrak
Penelitian ini bertujuan untuk menelaah kemampuan berpikir kritis matematis dan self confidence siswa yang memperoleh pendekatan Realistic Mathematic Education dibandingkan dengan yang memperoleh pembelajaran biasa. Metode yang digunakan dalam penelitian ini adalah metode eksperimen. Populasi dalam penelitian ini adalah Siswa SMP di Kabupaten Purwakarta, sedangkan sampelnya adalah SMP Negeri 1 Plered dan dipilih dua kelas secara acak dari seluruh kelas VII yang ada. Kemudian dari dua kelas tersebut ditetapkan secara acak yang menjadi kelas eksperimen dan kelas kontrol. Kelas eksperimen memperoleh pembelajaran dengan pendekatan Realistic Mathematic Education dan kelas kontrol memperoleh pembelajaran biasa. Instrumen yang digunakan adalah tes kemampuan berpikir kritis matematisdan skala self confidence. Dari hasil perhitungan dan uji hipotesis disimpulkan bahwa peningkatan kemampuan berpikir kritis matematis dan self confidence siswa yang memperoleh pendekatan Realistic Mathematic Education lebih baik daripada yang memperoleh pembelajaran biasa.
\end{abstract}

Kata Kunci: Berpikir Kritis, Self Confidence, Realistic Mathematic Education

How to cite: Delina, Afrilianto, M., \& Rohaeti, E. E. (2018). Kemampuan Berpikir Kritis Matematis dan Self Confidence Siswa SMP Melalui Pendekatan Realistic Mathematic Education. JPMI - Jurnal Pembelajaran Matematika Inovatif, 1 (3), 281-288.

\section{PENDAHULUAN}

Matematika merupakan salah satu disiplin ilmu dalam dunia pendidikan yang memegang peranan penting dalam perkembangan sains dan teknologi (Afrilianto, 2012). Matematika 
perlu diberikan kepada semua siswa mulai dari sekolah dasar, untuk membekali siswa dengan kemampuan berpikir logis, analitis, sistematis, kritis, inovatif dan kreatif, serta kemampuan bekerja sama. Kompetensi tersebut diperlukan agar siswa dapat memilki kemampuan memperoleh, mengelola dan mendapatkan informasi untuk hidup lebih baik pada keadaan yang selalu berubah, tidak pasti dan selalu kompetitif. Dalam pembelajaran, pemahaman konsep sering diawali secara induktif melalui pengamatan pola atau fenomena, pengalaman peristiwa nyata atau intuisi. Proses induktif-deduktif dapat digunakan untk mempelajari konsep matematika. Dengan demikian, cara belajar deduktif dan induktif digunakan samasama berperan penting dalam matematika. Dari cara kerja matematika tersebut diharapkan akan terbentuk sikap kritis.

Dalam kegiatan pembelajaran konvensional, proses pembelajaran biasanya diawali dengan menjelaskan konsep secara informatif, memberikan contoh soal dan diakhiri dengan soal latihan. Akibat dari pembelajaran tersebut siswa lebih diarahkan pada proses menghafal daripada memahami konsep. Belajar dengan menghafal tidak terlalu banyak menuntut aktivitas berpikir anak dan mengandung akibat buruk pada perkembangan mental anak. Anak akan cenderung mencari mudahnya saja dalam belajar. Anak kehilangan rangsangan untuk mau belajar, kebiasaan yang membuat anak bersifat pasif atau menerima begitu saja apa adanya mengakibatkan anak tidak terbiasa untuk berpikir kritis.

Proses pembelajaran konvensional tentu kurang dapat mengembangkan kemampuan berpikir kritis. Krulik dan Rudnick (Fachrurozi, 2011)mengemukakan bahwa yang termasuk berpikir kritis dalam matematika adalah berpikir yang menguji, mempertanyakan, menghubungkan, mengevaluasi semua aspek yang ada dalam suatu situasi ataupun suatu masalah. Berpikir kritis tersebut bisa muncul apabila dalam pembelajaran adanya masalah yang menjadi memicu dan diikuti dengan pertanyaan: "Menyelesaikan soal itu dengan cara yang lain", "Mengajukan pertanyaan bagaimana jika", "Apa yang salah", dan "Apa yang akan kamu lakukan" (Krulik dan Rudnick dalam Fachrurozi, 2011). Situasi seperti ini belum muncul dalam pembelajaran matematika konvensional, sehingga kemampuan berpikir kritis siswa kurang terlatih. Pada hal kemampuan berpikir kritis sangat dibutuhkan oleh siswa dalam mengatasi berbagai permasalahan dalam kehidupan sehari-hari.

Upaya memfasilitasi agar kemampuan berpikir kritis siswa berkembang menjadi sangat penting, mengingat beberapa hasil penelitian masih mengindikasikan rendahnya kemampuan berpikir kritis siswa Indonesia (Hidayat, 2011; 2012; Sumarmo, Hidayat, Zulkarnaen, Hamidah, \& Sariningsih, 2012). Hasil penelitian Suryanto dan Somerset (Zulkardi, 2001) terhadap 16 Sekolah Lanjutan Tingkat Pertama pada beberapa provinsi di Indonesia menunjukkan hasil tes mata pelajaran matematika sangat rendah, utamanya pada soal cerita matematika (aplikasi matematika). Kemampuan aplikasi merupakan bagian dari domain kognitif yang lebih rendah daripada kemampuan analisis, sintesis, dan evaluasi. Ketiga kemampuan tersebut digolongkan oleh Bloom (Duron, Limbach, \& Waugh, 2006) dalam kemampuan berpikir kritis.

Kemampuan berpikir kritis harus diiringi dengan aspek psikologis yang turut memberikan kontribusi terhadap keberhasilan seseorang dalam menyelesaikan tugas dengan baik. Aspek psikologis tersebut adalah self confidence. Menurut Walgio (Fitriani, 2015), salah satu untuk menumbuhkan self confidence adalah dengan memberikan suasana atau kondisi yang demokratis, yaitu individu dilatih untuk dapat mengemukakan pendapat kepada pihak lain melalui interaksi sosial, dilatih berfikir mandiri dan diberi suasana yang aman sehingga individu tidak takut berbuat kesalahan. Hal ini mendukung seorang guru harus mampu 
menciptakan suasana pembelajaran yang memberikan kebebasan siswa untuk melakukan interaksi baik antara siswa dengan siswa maupun antara siswa dengan guru melalui diskusi (Rahmi, Nadia, Hasibah, \& Hidayat, 2017).

Menurut Trends International Mathematics and Science Study (Fitriani, 2015) menunjukkan bahwa self confidence siswa Indonesia masih rendah dibawah 30\%. Self confidence menurut International Mathematics and Science Study yaitu memiliki matematika yang baik, mampu belajar matematika dengan cepat dan pantang menyerah, menunjukan rasa yakin dengan kemampuan matematika yang dimilikinya, dan mampu berfikir secara realistik. Dengan demikian, dapat disimpulkan bahwa self confidence penting untuk dimiliki oleh siswa. Melalui kerja kelompok atau diskusi, self confidence dapat dikembangkan, di sini siswa dituntut untuk mampu mengeksplorasi dan menemukan sendiri konsep-konsep matematika yang sedang dipelajarinya.

Untuk menumbuh kembangkan kemampuan berpikir kritis matematis dan self confidence siswa diperlukan suatu pendekatan pembelajaran matematika. Salah satu pendekatan pembelajaran matematika yang dapat digunakan untuk mengembangkan berpikir kritis matematis dan self confidence siswa adalah pendekatan Realistik Mathematic Education.

Realistic Mathematic Education merupakan salah satu pendekatan dalam pembelajaran matematika. Menurut Zainurie (Suciati, 2014), Realistic Mathematic Education adalah matematika sekolah yang dilaksanakan dengan menempatkan realitas dan pengalaman siswa sebagai titik awal pembelajaran. Masalah-masalah realistik digunakan sebagai sumber munculnya konsep-konsep matematika atau pengetahuan matematika formal. Pembelajaran matematika realistik di kelas berorientasi pada karakteristik-karakteristik Realistic Mathematics Education, sehingga siswa mempunyai kesempatan untuk menemukan kembali konsep-konsep matematika atau pengetahuan matematika formal. Selanjutnya, siswa diberi kesempatan mengaplikasikan konsep-konsep matematika untuk memecahkan masalah seharihari atau masalah dalam bidang lain.Adapun rumusan masalah dalam penelitian ini adalah: (1) Apakah kemampuan berfikir kritis matematis siswa SMP yang menggunakan pendekatan Realistic Mathematic Education lebih baik daripada yang menggunakan pembelajaran biasa?. (2) Apakah Self Confidence siswa yang menggunakan pendekatan Realistic Mathematic Education lebih baik daripada yang menggunakan pembelajaran biasa?. (3) Bagaimana implementasi pembelajaran matematika melalui Realistic Mathematic Education dikelas?. (4) Bagaimana kesulitan siswa dalam menyelesaikan soal berpikir kritis matematis?. Berdasarkan rumusan masalah tersebut tujuan penelitian ini bertujuan untuk mengetahui dan menelaah: (1) Kemampuan berpikir kritis matematis siswa yang pembelajarannya menggunakan pendekatan Realistik Mathematic Education dibandingkan dengan pembelajaran biasa. (2) Self Confidence siswa yang pembelajarannya menggunakan pendekatan Realistik Mathematic Education dibandingkan dengan yang menggunakan pembelajaran biasa. (3) Implementasi pembelajaran dengan menggunakan pendekatan Realistik Mathematic Education di lapangan.

(4) Kesulitan siswa dalam menyelesaikan soal-soal berpikir kritis.

\section{METODE}

Metode yang digunakan dalam penelitian ini adalah metode eksperimen dengan menggunakan desain penelitian berbentuk "pretes-postest control group" atau desain kelompok kontrol pretes-postes (Ruseffendi, 1998). Penelitian ini melibatkan dua kelas, yaitu kelas eksperimen dan kelas kontrol yang masing-masing pemilihannya dilakukan secara acak. Siswa pada kelas eksperimen memperoleh pembelajaran Pendekatan Realistic 
Mathematic Education, sedangkan siswa pada kelas kontrol memperoleh pembelajaran biasa. Sementara itu, tujuan dilaksanakan pretes dan postes adalah untuk menelaah kemampuan berpikir kritis siswa dan diberikan angket untuk mengetahui self confidence siswa.

Adapun desain penelitian yang digunakan pada penelitian ini adalah sebagai berikut:

A $\quad$ O $\quad X \quad O$

A $\quad \mathrm{O} \quad \mathrm{X} \quad \mathrm{O}$

\section{Keterangan}

A : Pemilihan sampel secara acak kelas

O: $\quad$ Pretes $=$ Postes

X: Pembelajaran dengan pendekatan Realistic Mathematis Education

\section{HASIL DAN PEMBAHASAN}

Berdasarkan hasil pengujian, diperoleh bahwa nilai postes kemampuan berpikir kritis matematis pada kelas eksperimen lebih baik daripada kelas kontrol. Hal ini menunjukan bahwa kemampuan berpikir kritis matematis siswa yang menggunakan pendekatan Realistic Mathematic Education lebih baik daripada yang menggunakan pembelajaran biasa.

Analisis data angket dilakukan dengan cara menentukan presentase jawaban responden siswa untuk masing-masing pertanyaan dalam angket yang selanjutnya dianalisis secara deskriptif. Presentase yang diperoleh pada masing-masing pertanyaan, kemudian ditafsirkan berdasarkan kriteria berikut:

$$
\begin{array}{ll}
\mathrm{P}=0 \% & \text { Tak seorang pun } \\
0 \%<\mathrm{P}<25 \% & \text { Sebagian kecil } \\
25 \% \leq \mathrm{P}<50 \% & \text { Hampir setengahnya } \\
\mathrm{P}=50 \% & \text { Setengahnya } \\
50 \%<\mathrm{P}<75 \% & \text { Sebagian besar } \\
75 \% \leq \mathrm{P}<100 \% & \text { Hampir seluruhnya } \\
\mathrm{P}=100 \% & \text { Seluruhnya }
\end{array}
$$

Penentuan presentase jawaban siswa untuk masing-masing item dan rata-rata secara keseluruhan pertanyaan dalam angket dengan menggunakan excel dan menunjukkan bahwa presentase rata-rata self Confidence siswa meningkat sebesar 54\%. Sebelum diberikan pendekatan Realistic Mathematic Education sebagian kecil sudah memilki self confidence. Setelah diberikan pendekatan Realistic Mathematic Education self confidence siswa meningkat menjadi $75 \%$. Adanya peningkatan $54 \%$ self confidence siswa dalam kelas eksperimen. 
Berdasarkan hasil pengolahan dan analisis data di atas, dapat dilihat bahwa kemampuan berpikir kritis matematis dan self confidence siswa yang menggunakan pendekatan Realistic Mathematic Education lebih baik daripada siswa yang menggunakan pembelajaran biasa. Dengan kata lain, pendekatan Realistic Mathematic Education lebih meningkatkan serta mengembangkan kemampuan berpikir kritis matematis dan self confidence siswa SMP kelas VII SMP Negeri 1 Plered Purwakarta daripada pembelajaran biasa.

Menurut Ennis (Mahmuzah, 2015), berpikir kritis sebagai berpikir reflektif yang beralasan dan difokuskan pada penetapan apa yang dipercayai atau yang dilakukan. Berpikir kritis berelasi dengan lima ide kunci yaitu praktis, reflektif, masuk akal, kepercayaan dan aksi. Selain itu, berpikir kritis juga mempunyai empat komponen yaitu kejelasan, dasar, inferensi, dan interaksi.

Berpikir kritis merupakan sebuah proses sistematis yang memungkinkan seseorang untuk merumuskan dan mengevaluasi keyakinan dan pendapatnya sendiri (Hendriana, Rohaeti, Sumarmo, 2017). Berpikir kritis juga merupakan proses terorganisasi yang memungkinkan seseorang mengevaluasi bukti, asumsi, logika dan bahasa yang mendasari pernyataan yang diterimanya. Dalam berpikir kritis segala kemampuan diberdayakan, baik itu memahami, mengingat, membedakan, menganalisis, memberi alasan, merefleksikan, menafsirkan, mencari hubungan, mengevaluasi bahkan membuat dugaan sementara.

Dalam belajar matematika, rasa percaya diri siswa harus kita tumbuhkan karena sikap ini sangatlah penting. Pada umumnya siswa malu untuk bertanya ketika mereka kurang mengerti tentang materi yang dijelaskan oleh guru, siswa malu untuk menjawab pertanyaan karena khawatir salah, siswa malu untuk menjawab soal di depan kelas, siswa mencontek ketika ujian. Sikap ini merupakan gambaran bahwa mereka kurang merasa percaya pada kemampuan diri mereka sendiri. Sebaliknya anak yang memiliki rasa percaya diri yang tinggi tidak akan takut untuk menjawab pertanyaan guru, tidak malu bertanya jika kurang paham materi tertentu, tidak malu mengerjakan soal di depan kelas, tidak akan mencontek ketika ujian, berusaha mengerjakan tugas sendiri dan tidak merasa takut mempelajari materi baru karena mereka yakin mereka mampu belajar matematika.

Menurut Hendriana, Rohaeti dan Sumarmo (2017), indikator utama rasa percaya diri (Self Confidence) sebagai berikut: (a) Percaya kepada kemampuan sendiri, (b) Bertindak mandiri dalam mengambil keputusan, (c) Memiliki konsep diri yang positif, (d) Berani mengungkapkan pendapat.

Menurut TIMSS (Isrok'atun, 2003) Realistic Mathematics Education (RME) diketahui sebagai pendekatan pembelajaran yang telah berhasil di Belanda. Siswa yang menggunakan pendekatan realistik mempunyai prestasi matematika yang tinggi. Pembelajaran matematika realistik pada dasarnya adalah pemanfaatan realitas dan lingkungan yang dipahami peserta didik untuk memperlancar proses pembelajaran matematika, sehingga mencapai tujuan pendidikan matematika secara lebih baik daripada yang lalu. Yang dimaksud dengan realita yaitu hal-hal yang nyata yang dapat diamati atau dipahami peserta didik lewat membayangkan, sedangkan yang dimaksud dengan lingkungan adalah lingkungan tempat peserta didik berada baik lingkungan sekolah, keluarga maupun masyarakat yang dapat dipahami peserta didik. Lingkungan dalam hal ini disebut juga kehidupan sehari-hari.

Adapun penerapan prinsip-prinsip pembelajaran dengan pendekatan Realistik Mathematic Education adalah sebagai berikut: (1) Bagaimana "guru" menyampaikan kontekstual sebagai 
starting point pembelajaran?. (2) Bagaimana "guru" menstimulasi, membimbing, dan memfasilitasi agar prosedur, algoritma, simbol, skema dan model yang dibuat oleh siswa mengarahkan mereka untuk sampai kepada matematika formal?. (3) Bagaimana "guru" memberi atau mengarahkan kelas, kelompok, maupun individu untuk menciptakan free production, menciptakan caranya sendiri dalam menyelesaikan soal atau menginterpretasikan masalah kontekstual, sehingga tercipta berbagai macam pendekatan, atau penyelesaian atau algoritma?. (4) Bagaimana "guru" membuat kelas bekerja secara interaktif sehingga interaksi diantara mereka, antara siswa dengan siswa dalam kelompok kecil dan antara anggotaanggota kelompok dalam presentasi umum, serta antara siswa dengan guru?. (5) Bagaimana "guru" membuat jalinan antara topik dengan topik lain, antara konsep dengan konsep lain, dan antara simbol dengan simbol lain di dalam rangkaian topik? (Suherman, Turmudi, Suryadi, Herman, Suhendra, Prabawanto, Nurjanah \& Rohayati, 2003)

Langkah-langkah dalam proses pembelajaran matematika dengan Realistic Mathematic Education menurut Horbri (Riadi, 2017) adalah sebagai berikut: (1) Langkah pertama, memahami masalah kontekstual, yaitu guru memberikan masalah kontekstual dalam kehidupan sehari-hari dan meminta siswa untuk memahami masalah tersebut. (2) Langkah kedua, menjelaskan masalah kontekstual Guru menjelaskan situasi dan kondisi soal dengan memberikan petunjuk/saran seperlunya terhadap bagian-bagian tertentu yang belum dipahami siswa. Penjelasan ini hanya sampai siswa mengerti maksud soal. (3) Langkah ketiga, menyelesaikan masalah kontekstual Siswa secara individu menyelesaikan masalah kontekstual dengan cara mereka sendiri. Guru memotivasi siswa untuk menyelesaikan masalah dengan cara mereka dengan memberikan pertanyaan/petunjuk/saran. (4) Langkah keempat, membandingkan dan mendiskusikan jawaban Guru menyediakan waktu dan kesempatan pada siswa untuk membandingkan dan mendiskusikan jawaban dari soal secara berkelompok. Untuk selanjutnya dibandingkan dan didiskusikan pada diskusi kelas. (5) Langkah kelima, menyimpulkan dari diskusi, guru mengarahkan siswa menarik kesimpulan suatu prosedur atau konsep, dengan guru bertindak sebagai pembimbing.

Untuk mendapatkan struktur kognitif dan afektif yang telah dimiliki siswa, dari lingkungan maupun pengalaman belajar tentang konsep yang akan diajarkan, maka diadakan semacam tes awal (pretes) dan mengisi angket self confidence. Hasil pengujian skor tes awal, kelas eksperimen maupun kelas kontrol tidak dapat perbedaan yang signifikan dalam kemampuan berpikir kritis matematis siswa. Hal ini membuktikan bahwa kedua kelas bersifat homogen.

Hasil penelitian ini, memberikan gambaran bahwa pendekatan Realistic Mathematic Education memberikan pengaruh yang positif terhadap kemampuan berpikir kritis matematis dan self confidence siswa.

\section{KESIMPULAN}

Berdasarkan hasil penelitian dan pengolahan data pada keseluruhan tahapan penelitian dengan mengacu pada rumusan masalah yang dikemukakan pada pendahuluan, maka dapat diambil kesimpulan: (1) Kemampuan berpikir kritis matematis siswa yang pembelajarannya menggunakan pendekatan Realistic Mathematic Education lebih baik daripada yang menggunakan pembelajaran biasa. (2) Self confidence siswa yang menggunakan pendekatan Realistic Mathematic Education lebih baik daripada yang menggunakan pembelajaran biasa. (3) Implementasi pendekatan Realistic Mathematic Education pada penelitian ini berjalan dengan baik. (4) Siswa dapat mengatasi kesulitan dalam menyelesaikan soal kemampuan berpikir kritis matematis. Kesimpulan yang dikemukakan di atas memberikan saran sebagai 
berikut: (1) Pendekatan Realistic Mathematic Education hendaknya menjadi alternatif strategi pembelajaran bagi guru SMP/ MTs khususnya dalam meningkatkan kemampuan berpikir kritis matematis siswa. (2) Untuk menerapkan pembelajaran dengan pendekatan Realistic Mathematic Education, sebaiknya guru membuat sebuah alat peraga atau media yang lebih baik, sehingga pendekatan Realistic Mathematic Education dapat diterapkan dengan baik. (4) Agar Realistic Mathematic Education tidak asing bagi siswa dan mudah diterapkan, sebaiknya dari mulai tingkat sekolah dasar sudah mulai diperkenalkan dengan memilih materi yang sesuai dengan karakteristik pendekatan Realistic Mathematic Education. (5) Perlunya self confidence siswa yang dapat dilakukan menggunakan pendekatan Realistic Mathematic Education di setiap materi yang sesuai.

\section{DAFTAR PUSTAKA}

Afrilianto. (2012). Peningkatan Pemahaman Konsep dan Kompetensi Strategis Matematis Siswa SMP dengan Pendekatan Metaphorical Thinking. Jurnal Ilmiah Program Studi Matematika STKIP Siliwangi Bandung, 1(2), 192-202.

Duron, R., Limbach, B., \& Waugh, W. (2006). Critical Thinking Framework For Any Discipline. International Journal of Teaching and Learning in Higher Education, 17(2), 160-166. https://doi.org/10.1016/j.nepr.2006.09.004

Fachrurozi. (2011). Penerapan Pembelajaran Berbasis Masalah Untuk Meningkatkan Kemampuan Berpikir Kritis Dan Komunikasi Matematis Siswa Sekolah Dasar. Jurnal Penelitian Pendidikan UPI, (1), 76-89. https://doi.org/10.1017/CBO9781107415324.004

Fitriani, N. (2015). Hubungan Antara Kemampuan Pemecahan Masalah Matematis Dengan Self Confidence Siswa SMP Yang Menggunakan Pendekatan Pendidikan Matematika Realistik. Jurnal Euclid, 2(2), 341-351.

Hendriana, H., Rohaeti, E. E., Sumarmo, U. (2017). Hard Skill dan Soft Skill Matematik Siswa (1st ed.). Bandung: Refika Aditama.

Hidayat, W. (2011). Meningkatkan Kemampuan Berpikir Kritis dan Kreatif Matematik Siswa Melalui Pembelajaran Kooperatif Think-Talk-Write (TTW) (Doctoral dissertation, Universitas Pendidikan Indonesia).

Hidayat, W. (2012). Meningkatkan Kemampuan Berpikir Kritis dan Kreatif Matematik Siswa SMA Melalui Pembelajaran Kooperatif Think-Talk-Write (TTW). In Seminar Nasional Penelitian, Pendidikan dan Penerapan MIPA.

Isrok'atun. (2003). Meningkatkan Komunikasi Matematik Siswa Smp Melalui Realistic Mathematics Education ( Rme ) Dalam Rangka Menuju Sekolah Bertaraf Internasional ( Sbi ) Meningkatkan Komunikasi Matematik Siswa Smp Melalui Realistic Mathematics Education ( Rme ) Dalam Rangka, 1-11.

Mahmuzah, R. (2015). Peningkatan Kemampuan Berpikir Kritis Matematis Siswa SMP melalui Pendekatan Problem Posing. Jurnal Peluang, 4(1), 64-72.

Rahmi, S., Nadia, R., Hasibah, B., \& Hidayat, W. (2017). The Relation between Self-Efficacy toward Math with the Math Communication Competence. Infinity Journal, 6(2), 177182. 
Riadi, M. (2017). Pembelajaran Realistic Mathematic Education (Online). In kajianpustaka.com. Retrieved from www.kajianpustaka.com/2017/10/pembelajaranrealistic-mathematics-education.html

Ruseffendi, E.T. (1998). Statistika Dasar untuk Penelitian Pendidikan. Bandung: IKIP Bandung Press.

Suciati. (2014). Meningkatkan Kemampuan Pemahaman Matematis Siswa SMP dengan Pendekatan Realistic Mathematic Education. Skripsi Program Pendidikan Matemataika STKIP Siliwangi Bandung: Tidak diterbitkan.

Suherman, E., Turmudi, Suryadi, D., Herman, T., Suhendra, Prabawanto, S., Nurjanah dan Rohayati, A. (2003). Strategi Pembelajaran Matematika Kontemporer. Bandung: UPI.

Sumarmo, U., Hidayat, W., Zukarnaen, R., Hamidah, M., \& Sariningsih, R. (2012). Kemampuan dan Disposisi Berpikir Logis, Kritis, dan Kreatif Matematik (Eksperimen terhadap Siswa SMA Menggunakan Pembelajaran Berbasis Masalah dan Strategi Think-Talk-Write). Jurnal Pengajaran MIPA, 17(1), 17-33.

Zulkardi. (2001). Realistic Mathematic Education (RME). Teori, Contoh Pembelajaran dan Teman Belajar di Internet. Makalah Seminar Nasional Matematika, (4 November 2001) UPI : Tidak diterbitkan 